\title{
Research foundations tight-lipped about investment losses
}

$\mathrm{F}$ ears that the ongoing international financial crisis may mean tougher grant competitions at health research agencies and foundations this year may be unwarranted as officials at several organizations say they're weathering the market turmoil relatively well.

Conservative investment strategies appear to have shielded several foundations from the worst effects of rollercoaster stock markets, which have typically resulted in at least 10\%-20\% losses in value of the average Canadian's retirement savings plans and other investment portfolios.

In the late-1990s, the federal government began turning to foundations as a way of delivering public policy objectives. Since then, more than $\$ 9$ billion has been transferred from federal coffers to foundations, many of which fund health research. Several provincial health research foundations, with large sums to disburse, were also created and funded through endowments or through periodic government contributions from general revenues.

For the most part, the foundations report that they're in good financial shape, though no one offered detailed figures.

"We landed in the first quartile for the third quarter, so we've done better than most [funds]" says Nancy Quattrocchi, vice-president of corporate services for the Canadian Health Services Research Foundation, which funds its operations from an endowment that was valued at $\$ 104$ million at the end of 2007.

"Not to say we wouldn't have lost money if we had cashed out," she adds.

Manon Harvey, vice-president finance for the Canadian Foundation for Innovation, says the projects funded by her organization won't be affected by the market downturn because the organization's investments are held to maturity. At the end of March 2008, they had a market value of $\$ 2.3$ billion. The foundation was originally scheduled to sunset by 2010, but the federal government has indicated that it plans to continue the foundation's operations. To do so, new infusions of cash will be advanced "on a need basis," Harvey says.

Other foundations are taking the

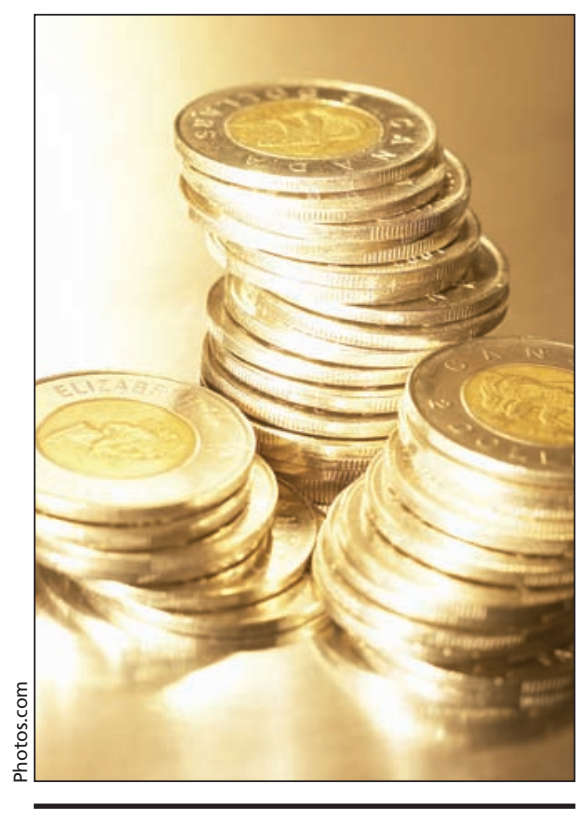

Canada's research foundations are taking a long-term view regarding the stability of their investment portfolios.

view that they'll eventually recover from current losses in their portfolios.

The Alberta Heritage Foundation for Medical Research, established in 1980 with a \$300-million endowment from the provincial government that was topped up by $\$ 500$ million in 2005 , is "suffering the same impact now as other diversified endowment funds," explains interim president Jacques Magnan. "But we have to take the long-term view that the positive returns will come back at some point in time."

Research requires stable funding so "we've taken the approach of not yoyoing from year to year," says Magnan, explaining that in years of higher yields, the foundation reinvests some of its earnings. The Foundation's portfolio, valued at $\$ 1.53$ billion on Mar. 31, 2008, is managed by the Alberta Investment Management Corporation.

Oversight of the investment strategies of Canada's major health research foundations appears to differ, although there is a push to standardize those that have received federal funding.

For example, Quattrocchi's foundation was free to make investments as its board saw fit, until 2003.

But a 2003 cash injection from Health Canada came with terms and conditions (i.e., specific investment criteria) and the foundation is now negotiating with Health Canada about how to implement the Finance ministry's latest guidelines, Quattrocchi says. The March 2007 guidelines, Ministry of Finance Investment Management Framework for Up-front Funding, outline rules to ensure "prudent" investment. They apply to organizations with endowment funds greater than $\$ 100$ million, as well as those, such as the Canadian Foundation for Innovation, which were given lump sums to be spent over a predetermined period of time. The former must have investment policies approved by the Department of Finance, as well as by their own board of trustees, while the latter do not.

The framework sets quantitative limits on certain types of investments. Guidelines for organizations with limited life spans are stricter than for those with endowments - for example, prohibited investments for the former include equities or shares issued by any corporation and hedge funds. For both types of organizations, "derivatives or any instruments that have derivative holdings or features" are prohibited investments.

Meanwhile, the rules have changed for some — but not all — foundations receiving new federal multiyear grants and contributions. Money for those affected by the change will remain in the Consolidated Revenue Fund and will be advanced "based on the actual cash requirements of the recipients" in a given year, according to a Treasury Board spokesperson. As a result, such foundations will no longer have earnings from investments.

This change applies to foundations that are "controlled" for accounting purposes, the spokesperson said. The Canada Foundation for Innovation is deemed to be controlled, while Genome Canada (which declined comment on its investments) is not.

British Columbia's Michael Smith Foundation for Health Research, with investments valued at $\$ 26.2$ million on Mar. 31, 2008, is seeking an annualized or multiyear cash injection from the province. - Ann Silversides, CMAJ

DOI:10.1503/cmaj.081942 